DOI: https://dx.doi.org/10.26808/rs.ca.i10v5.04

International Journal of Computer Application (2250-1797)

Issue 10 Volume 5, September- October 2020

\title{
An Exploration of Mobile App asa Reporting Solution to Bullying in Indian Schools
}

Ayaan Shah

Ahmedabad International School, Ahmedabad, India

Purpose: This research paper aims to understand the bullying experiences of Indian adoloscents, their preferences regarding a bullying reporting system, specifically a mobileapplication based one, from the viewpoint of students and teachers. It also assesses the need for, and the preferred features of a mobile app for use by adolescents for reporting bullying in Indian schools.

Design/methodology/approach: Two separate surveys were conducted for adolescents studying in grades 5 to 12 (sample size of 210) and teachers teaching grades 5-12 (sample size of 30). The research instruments were questionnaires with close-ended questions administered electronically.

Findings:The study finds that verbal and social bullying are far more frequent than those relating to physical bullying.Most bullying incidents occur in the presence of bystanders. The study also identifies the top three preferred methods of reporting bullying. It lists the most preferred attributes of an ideal reporting system and of a mobile-app based bullying reporting system from the perspective of students and teachers.

Practical implications: The insights generated by this research have been incorporated into the development of the mobile application 'Upstander' created by the researcher. The findings of this study will also provide a valuable reference point for other developers of bullying related apps.

Originality/value:There is no existing study that has taken a systematic in-depth approach to exploring Indian adolescents' experiences about bullying and their requirement for a bullying reporting system in a technological format.

Keywords:bullying, India, reporting system, mobile application, students, teachers

\section{Introduction}

Existing research shows that between 30 and 80 per cent of school students are affected by bullying (Graham, 2010), and timely reporting that leads to correct intervention is essential in order to reduce the negative effects of bullying for young people (Morgan, 2012). One of the most commonly faced challenges is how to develop effective reporting systems that are acceptable to adolescents and an innovative means of doing this is through mobile technology (Kenny, Dooley and Fitzgerald, 2016).

Recent technological advances have made available more sophisticated and affordable mobile devices. The increasing use of mobile applications (also called apps) makes them ideal for delivering cost-effective interventions, which can be used in the users' natural environments (Heron and Smith, 2010).Such mobile phone based applications may be particularly salient 
DOI: https://dx.doi.org/10.26808/rs.ca.i10v5.04

International Journal of Computer Application (2250-1797)

Issue 10 Volume 5, September- October 2020

for Indian adolescents. A recent study reveals that 88 percent of Indian adolescents aged between 15 and 18 years own mobile phones, while 40 percent of Indian teenagers aged 1315 have access to them regularly (Mobile Indian Network, 2018). The use of mobile technology for such a purpose in India would also be greatly helped by the fact that India has the lowest cost of internet globally, around USD 0.26 per GB (McCarthy, 2019).

Mathews et al (2008) maintain that adolescents use their phones on a daily basis and are likely to find them appealing as a familiar intervention medium.Furthermore, mobile interventions canbe used at any time, in any place, and they afford a high degree of convenience and confidentiality. Currently, there is little research on the use of mobile technologies or applications in reporting or addressing bullying, particularly in the Indian context.

This paper demonstrates a growing demand for the design and development of an evidencebased bullying reporting mobile application that can be used effectively by adolescents to report bullying to their schools. However, there is currently a lack of research exploring users' (students') needs for a bullying reporting app and their expectations from it.

Some studies have attempted to demonstrate the utility of technology for use with adolescents in areas such as formative assessment (Graesser \& McDaniel, 2007), self-reflection (Song, Rice, \& Oh, 2019), and students' attitude changes (Arroyo, Woolf, Cooper, Burleson, \& Muldner, 2011; Kim \& Wei, 2011). However, the use of technology in anti-bullying programs has been under-investigated.

There is a lack of understanding about the important features of any technological intervention that deals with bullying as well as the issues considered important by adolescents in the development process of a mobile technology intervention that counters bullying.

Understanding the specific end user needs is the firststep in designing any kind of technology-based intervention (Mathews et al, 2008; ISO, 2010). Additionally, the cultural context of the end users cannot be ignored too. Researchers must develop a thorough understanding of adolescents' needs to ensure that they can be appropriately met through bullying mobile apps. If this is done, young people will be more likely to use these apps, which will increase their overall reach and impact (Peterson-Sweeney, 2005).

However, to the best of the author's knowledge, there is no existing study that has taken a systematic in-depth approach to exploring Indian adolescents' experiences about bullying and their requirement for a bullying reporting system in a technological format.

The aim of this study is to address this gap in the existing research and inform the development of a bullying reportingmobile app by:

1) exploring Indian adolescents' experiences with bullying

2) understanding Indian adolescents'perspectives on the alternatives available to them for reporting of bullying

3) understandingIndian adolescents' preferences about the features of a bullying reporting mobile app

4) understanding the perspective of Indian schoolteachers on bullying reporting systems for their students 
DOI: https://dx.doi.org/10.26808/rs.ca.i10v5.04 International Journal of Computer Application (2250-1797)

Issue 10 Volume 5, September- October 2020

The paper is organized as follows. The next section deals with an in-depth literature review about bullying worldwide and in India, the various types of interventions and reporting systems for bullying used by schools, the role of bystanders and the emerging use of technology in this area. The next section discusses the research methodology adopted. This is followed by the findings of the comparative study of existing bullying apps, and the findings of the two surveys conducted with two stakeholder groups (students and teachers). The conclusions from the findings are presented in terms of their applicability and use as inputs for the development of a mobile application for reporting bullying created by the researcher. Finally, the discussion section provides the practical implications of the study for the development of a mobile app by developers in the future. It also discusses limitations and further scope for research.

\section{Literature Review}

\section{Bullying}

Academic literature defines bullying as involving repeated aggressive behaviour directed towards someone with less power, with the intention of causing them harm (Rigby \& Smith, 2011). However, this definition cannot be applied to every complex setting in every school community (Maunder et al, 2018).

Olweus (2013) defines bullying as an unprovoked form of aggressive peer-peer behavior with three characteristics that make it different from other peer interactions: "(a) negative actions, either verbal or physical, directed toward the victim with the aim of hurting them, (b) an imbalance of power or an asymmetrical power relationship favouring the bully and rendering the victim incapable of defending himself or herself, and (c) negative actions being repeated over time" (Olweus 2013, p. 757).

Naylor, Cowie, Cossin, de Bettencourt and Lemme (2006) attempted to define bullying through responses of pupils and teachers to the question 'Say what you think bullying is'. In comparison to teachers, pupils tended to limit their definitions of bullying to verbal or physical forms and neglected indirect behaviours such as social exclusion. In a similar research, Smith, Cowie, Olfasson and Liefooghe (2002) found that pupils of different ages interpret the meaning of bullying in varied ways. Research also shows that younger pupils tend to adopt a broader definition of bullying than older pupils (Smith \& Levan, 1995).

Teachers have indicated that the identification of bullying depends on the situation, and organisational factors such as relationships between colleagues, relationships with pupils, and institutional procedures shape how incidents are dealt with. There are also contextual factors about incidents that determine whether they are perceived as bullying, and whether or not teachers will intervene (Maunder et al, 2019).

Smith and Monks (2008) discuss evidence that i) the academic definition of bullying is not necessarily shared by others in the population ii) there are age-related trends in how bullying is understood iii) terms used to describe bullying differ across cultures, and iv) the type of bullying behaviour displayed may vary between cultural groups.

Early research on bullying paid attention only to physical and verbal bullying (Olweus, 1978) and it was only in the 1990s where indirect and relational forms of bullying were fully recognised (Smith et al., 2002). The growth of technology has also opened up new typologies of bullying using cyberspace (Law, Shapka, Hymel, Olson, \& Waterhouse, 2012; Williams \& Guerra, 2007), and a new label of 'cyberbullying' has been added to the vocabulary (Maunder et al, 2019).

It is not surprising that academic research and school policy aim to reach a unifying definition of bullying in school. However, the studies discussed above are valuable for showing that definitions are not straightforward and that attention needs to be given to stakeholders' interpretations of bullying when planning interventions (Maunder et al, 2019). 
DOI: https://dx.doi.org/10.26808/rs.ca.i10v5.04

International Journal of Computer Application (2250-1797)

Issue 10 Volume 5, September- October 2020

While much of the literature on bullying is based on studies in the Western world, there is growing interest in research in this field in India and other parts of Asia. Over the past decade, researchers have explored in-person bullying in the Indian context (Solomon et al. 2013; Srisiva et al. 2013; Sundaram and Alexander 2012).

While studies on school bullying in Asian countries like India are limited, it is found that violence is prevalent among school children. It is believed that prevalence rates are higher in developing countries, as indicated by Chen and Astor who surveyed junior high students in Taiwan. Several studies like Ramya (2011) found that the prevalence rate for bullying in India was among the highest in the world. Studies like Kshirsagar (2007) indicate that name calling was the most common form of bullying whereas physical harm was the least common.

\section{Dealing with Bullying in Schools}

A review of the literature makes it clear that bullying has now moved from being regarded as a natural part of growing up to being seen as "a demanding social and public health issue that schools and educational authorities must take seriously and counteract" (Olweus, 2013, p. 775).

For any interventions to be taken against bullying, it is important for the victims to come forward and report their experiences of bullying. However, Ramya (2011)found that most victims did not confide instances of bullying with anyone, including their parents. The victims' confidence about sharing their bullying experience increased in friends and decreased in teachers with increasing age. Surprisingly, a significant number of parents encouraged their children to compromise, indicating their perceived insignificance of bullying.

The high prevalence rates of bullying and parental unawareness may be credited to the fact that most Indian schools lack school counsellors and school psychologists who would otherwise be responsible for leading initiatives to solve student problems like bullying. While the need for addressing psychological and social needs of students in schools is being felt in India, most schools do not have a counsellor, nor are there many training programs for school counsellors (Kodad and Kazi, 2014).

Further, there appears to be dissonance in the expected role of a school counsellor, with parents and teachers expecting counsellors to address academic advising, student discipline, conflict resolution, crises intervention, and career choice and guidance (Venkatesan \& Shyam, 2015), rather than focusing on student issues such as bullying.

\section{Interventions for reporting and countering bullying}

There is a distinct lack of interventions regarding reporting and countering bullying in schools all over the world, and especially in India. Teachers are often not aware ofthe occurrence of bullying, or they may confuse it with play (Craig, Henderson, \&Murphy, 2000; Kikkawa, 1987; Stockdale, Hangaduambo, Duys, Larson, \&Sarvela, 2002). Teachers may also not be aware of effective intervention strategiesor be confident in their ability to handle bullying (Boulton, 1997; Bauman \& delRio, 2005). Therefore it seems that the low level of intervention against bullying is due to a general lack ofawareness of teachers about the incidence of of bullying, itsconsequences on the victims, or effective ways to handle the problem.

It is important for teachers to effectively recognize bullying, since victims oftendo not tell anyone (Kikkawa, 1987; Rigby, 1997). Anti-bullying measures can only be effective if teachers are aware of the existence of bullying in the first place. This makes the existence of an effective reporting system crucial. 
DOI: https://dx.doi.org/10.26808/rs.ca.i10v5.04 International Journal of Computer Application (2250-1797)

Issue 10 Volume 5, September- October 2020

The reporting of bullying has been emphasized in several studies over the years. Olweus (1993) proposed that students should be encouraged to tellteachers about the occurrence of bullying. A project conducted by Beale and Scott (2001) involved students being urged to sign an anti-bullying pledge (which included a promise to report bullying behaviours, among other things), and reported a $20 \%$ reduction in the number of bullying incidents at the middle school level. Milson and Gallo (2006) have provided suggestions for teachers being more aware of bullying and having more students reporting incidents of bullying to them. Despite the crucial role of teachers in managing the problem of reporting of bullying, relatively little research has been conducted to understand teachers' views on reporting of bullying.

There is a lot of disagreement on the efficacy of bullying prevention programs (Lanigan, 2015). While Farrington and Ttofi (2009) found a 20-23 percent decrease in bullying and claimed greater efficacy of these programs in older students, Yeager (2014) found that highschool adolescents do not show any significant trend in reduced bullying after being involved in anti-bullying programs. Evans (2014) concluded that although some evidence suggests that anti-bullying programs could achieve positive results, several programs are actually ineffective.

In order to combat these difficulties, several researchers have emphasized an effective system for reporting bullying as the first step towards an effective bullying prevention program. Milsom and Gallo (2006) recognize the need for information regarding frequency, location, and type of bullying. One of the most successful programs, the Olweus Bullying Prevention Program, currently being used in over 6,000 schools in the USA, includes a list of behaviors to be inculcated among children and teachers. Prominent among these is children being encouraged to report bullying to teachers, and teachers paying attention to parent and student reports involving bullying (Morgan, 2012).

Research has also attempted to identify the ideal bullying reporting system. Novick and Isaacs (2010) indicate that students are often hesitant in involving teachers as they often fear that teachers will reveal their identity, which could result in retaliation, or that their report of harassment will be dismissed out-of-hand. To remedy this, Allen (2010b) suggests the use of a reporting form, offering anonymity for students, and Novick and Isaacs (2010) emphasize the need for an environment where reporting bullying feels safe.

\section{Bystanders to Bullying in Schools}

The phenomenon of bullying involving bullies and victims as well as bystanders (Olweus, 1993; Salmivalli, 1999; Salmivalli \& Peets, 2009).O'Connell, Pepler and Craig (1999) maintain that most members of the victim's peer group are well aware that bullying is taking place in their immediate vicinity. Craig and Pepler (1997) showed that peers were bystanders in 85 percent of bullying incidents, while Salmivalli et al (1996) found the majority of students admitting that they witnessed school bullying. In two Canadian studies, 60 percent of students in Grades 3 to 6 reported witnessing verbal bullying in the past four weeks (Aboud \& Miller, 2007), and 87 percent of students in Grades 8 to 10 reported witnessing bullying at school in the past year (Bonanno \& Hymel, 2006a, 2006b).

However, while the presence of bystander is well recorded, several studies show that bystanders intervened on behalf of victims in only 25 percent of bullying incidents. (Craig \& Pepler, 1997; O'Connell et al., 1999). Only 17 percent of students were recognised by peers as 'defenders' who intervened on behalf of the victims (Salmivalli et al, 1998).

The bystanders who do intervene on behalf of their peers being bullieddeploy various strategies. Henderson (2002) found the most common strategies used by Canadian students being talking to the bully and supporting the victim (both mentioned by 18 percent of students), followed by direct intervention and seeking adult involvement (13 percent each). In England and Japan, students generated three major bystander responses: take direct action/get 
DOI: https://dx.doi.org/10.26808/rs.ca.i10v5.04

International Journal of Computer Application (2250-1797)

Issue 10 Volume 5, September- October 2020

involved (endorsed by 66 percent of the sample), seek help from teachers, parents, or friends (39 percent), and support the victim (Kanetsuna, Smith, \& Morita, 2006).

Thus, bystanders to bullying form an important stakeholder group that can help support the victim in a variety of ways, most importantly by reporting the bullying incident to responsible adults (Novick and Isaacs, 2010).

\section{Use of Technology in Reporting and Preventing Bullying}

Several studies have explored the use of mobile technologies to supplement mental health awareness and intervention programmes with adults and have been found to be effective (Dow et al 2003; Kristjánsdóttir, 2013). Existing research suggests that interventions for mental health and social issues through mobile technologies may prove effective for adolescents too (Whittaker et al, 2012), especially those based on self-monitoring principles (Kauer, 2012).

Proudfoot (2013) predicts a rapid increase in the use of mobile technologies for mental health and social issues. There is already a plethora of such programs available to the general public as mobile applications or 'apps'. In 2012, Mobi HealthNews reported that over 700 mental health apps were available to download in the Apple App Store alone (Proud foot, 2013). Similarly, the use of mobile apps for bullying is an area that is expected to grow, going by the indication that currently there are almost 40 apps that deal with bullying on the Apple App Store and Google Play Store in October 2020.

However, most of these bullying related apps have been promoted by designers from Western countries. Similar to the general mental health apps, they are not subject to regulatory assessments or evaluations, thus their effectiveness cannot be verified (Breton, 2011).

There is some existing research on the characteristics of an ideal mobile app that would maximise engagement with children and adolescents. Noorhidawati, Ghalebandi and Hajar (2015) disclose three main conditions that effective mobile apps must possess to engage this age group based on the notions of "i) collective sensory skill; ii) emotional expression; and iii) verbal expression".

Anonymous reporting of bullying through a computer program has been suggested by Nocentini, Zambuto and Menesini (2015) and Limper (2000). Frey et al. (2009) suggested theuse of real-time technology based programs as an effective way to monitor potential bullyingissues and provide schools with detailed information about bullies, victims, and bystanders'behaviors and attitudes, which is the key for the stopping bullying. Oh, Song and Hong (2020) also suggest a computerized method of implementing an anti-bullyingprogram using a conversation-bot.

It is becoming exceedingly clear that anti-bullying reporting programs need to actively adopt latest technology and new tools for their effectiveness. Conventional programs consisting of direct instruction and verbal reporting have not proven to be sensitive enough to students' needs.

The linkage between research and practice could be the key to successfully designing an effective bullying reporting system. Programs need to be designed to raise awareness regarding bullying and to encourage the increase of student reporting of bullying. At the same time, practical considerations such as affordance, convenience, and user-friendliness should not be ignored when designing such a system (Oh, Song and Hong, 2020). 
DOI: https://dx.doi.org/10.26808/rs.ca.i10v5.04

International Journal of Computer Application (2250-1797)

Issue 10 Volume 5, September- October 2020

This study attempts to find out the experiences of two important stakeholder groups students and teachers - regarding their experience with bullying and investigates their preferences for an effective reporting system, especially a mobile application based one. Based on the findings of the two surveys, it then outlines the most desirable characteristics of a mobile-app based bullying reporting system and proceeds to demonstrate the prototype of such an app.

\section{Research Methodology}

As mentioned earlier, this research paper deals with the following research questions:

$R Q$ 1: What are the experiences of Indian adolescents regarding bullying in schools?

$R Q$ 2: What are the perspectives of Indian adolescents on the alternatives available to them for reporting of bullying?

$R Q$ 3: What are the preferences of Indian adolescents about the features of a bullying reporting mobile app?

RQ4: What are the preferences of Indian teachers about alternatives available to their students for reporting of bullying and the features of a bullying reporting mobile app?

Since this was an exploratory study, the first step was to undertake a review and analysis of the existing mobile apps that deal with bullying. Using the keyword 'bullying' on Apple App Store and Google Play Store, around 40 apps were discovered. However, based on a careful review and an analysis of usage patterns, six apps were found to deal with bullying in a concrete manner. A comparative analysis of the six apps was conducted and the findings of the same are presented in Table 1.

Two separate surveys were conducted for the two stakeholder groups - adolescents studying in grades 5 to 12 (ages 10 to 19), and teachers teaching grades 5-12. The sample size for the students' survey was 200 , but it generated 210 responses. The sample size for the teachers' survey was 30. The research instrument for both the surveys was a questionnaire with closeended questions that was administered electronically via email and WhatsApp. The sampling method used was cluster sampling, where students and teachers from clusters (in this case, schools in Ahmedabad city) were included in the sample.

\section{Findings}

\section{Comparative Analysis of Existing Apps Dealing with Bullying}

Six existing bullying reporting applications and software were reviewed in order to gauge popular features. Investigating availability across platforms, it was found that only three out of the six applications were available on all platforms - Android, IOS, and the Web.

Investigating availability in India, it was found that only three apps offered their services to users in India while most applications had been developed for United States School Districts.

As Table 1 shows, a school side interface to aid the school administration in managing complaints and generating reports was a popular feature and present in five out of the six apps. However, it is speculated that the reason for this could be the fact that the primary consumers of the app were schools that purchased a subscription to use it and not the students themselves. This also gives these applications access to school records, and hence the ability to verify that users are indeed enrolled students. Other popular features included allowing bystanders to report bullying incidents that they witness ( 83 percent), allowing the reporter to remain anonymous ( 83 percent), and allowing the student to submit evidence in the form of images and video and audio recordings (67 percent). Less popular features include the ability 
DOI: https://dx.doi.org/10.26808/rs.ca.i10v5.04 International Journal of Computer Application (2250-1797) Issue 10 Volume 5, September- October 2020

to reveal partial details about the reporter's identity (17 percent) and an anonymous messaging service between the school administration and the reporter (50 percent).

Table 1: Comparative Analysis of Existing Apps Dealing with Bullying

\begin{tabular}{|l|l|l|l|l|l|l|}
\hline & $\begin{array}{l}\text { Go } \\
\text { SpeakUp! }\end{array}$ & $\begin{array}{l}\text { Anonymous } \\
\text { Alerts }\end{array}$ & $\begin{array}{l}\text { Bully } \\
\text { Button.com }\end{array}$ & BRIM & $\begin{array}{l}\text { Anti- } \\
\text { Bullying } \\
\text { App }\end{array}$ & StopIt \\
\hline $\begin{array}{l}\text { Available } \\
\text { on Web, } \\
\begin{array}{l}\text { Android, } \\
\text { IOS }\end{array}\end{array}$ & Not Web & Yes & Web only & Yes & No & Yes \\
\hline $\begin{array}{l}\text { Available in } \\
\text { India }\end{array}$ & Yes & No & No & No & Yes & Yes \\
\hline $\begin{array}{l}\text { Has school- } \\
\text { side } \\
\text { interface }\end{array}$ & Yes & Yes & Yes & Yes & No & Yes \\
\hline $\begin{array}{l}\text { Has Good } \\
\text { Samaritan } \\
\text { bystander) } \\
\text { angle }\end{array}$ & Yes. Not & $\begin{array}{l}\text { Yes, not } \\
\text { specific }\end{array}$ & $\begin{array}{l}\text { Yes, very } \\
\text { complex }\end{array}$ & Yes & No & Yes \\
\hline $\begin{array}{l}\text { Has } \\
\text { anonymity } \\
\text { option }\end{array}$ & Yes & Yes & Yes & Yes & No & Yes \\
\hline $\begin{array}{l}\text { Has partial } \\
\text { anonymity } \\
\text { option }\end{array}$ & No & No & Yes & No & No & No \\
\hline $\begin{array}{l}\text { User } \\
\text { verification } \\
\text { process }\end{array}$ & Yes & Yes & No & Yes & No & Yes \\
\hline $\begin{array}{l}\text { Attach } \\
\text { video/ }\end{array}$ & Yes & Yes & Yes & No & Yes \\
\hline Messaging & Yes & No & No & \\
\hline
\end{tabular}

\section{Prevalence of Bullying in Schools}

Both the stakeholder groups of students and teachers were asked about the frequency of bullying behaviours either experienced by them (in case of students) or observed by them (in case of teachers, and by students as bystanders). Table 2 shows the frequency of various types of behaviours that are classified as bullying behaviours by Olweus (1996). 
Table 2: Frequency of Bullying Behaviors

\begin{tabular}{|l|l|l|l|l|}
\hline Bullying Behaviors & $\begin{array}{l}\text { Multiple } \\
\text { times } \\
\text { week }\end{array}$ & $\begin{array}{l}\text { 2 to 3 times } \\
\text { a month }\end{array}$ & $\begin{array}{l}\text { Only once or } \\
\text { twice }\end{array}$ & Never \\
\hline Saying mean or hurtful things & 13.33 & 14.76 & 37.14 & 34.76 \\
\hline $\begin{array}{l}\text { Ignoring or excluding the } \\
\text { ttudent }\end{array}$ & 9.53 & 11.43 & 25.71 & 53.33 \\
\hline $\begin{array}{l}\text { Hitting, kicking, pushing, } \\
\text { shoving or locking in a room }\end{array}$ & 1.90 & 3.81 & 12.86 & 81.43 \\
\hline $\begin{array}{l}\text { Spreading false rumors, causing } \\
\text { unpopularity }\end{array}$ & 9.52 & 7.14 & 31.43 & 51.90 \\
\hline $\begin{array}{l}\text { Sending mean messages/emails } \\
\text { or emailing rumors }\end{array}$ & 3.33 & 2.38 & 20.48 & 73.81 \\
\hline $\begin{array}{l}\text { Posting negatively on social } \\
\text { media }\end{array}$ & 0.95 & 1.90 & 14.76 & 82.38 \\
\hline
\end{tabular}

As Table 1 shows, a large majority of the student respondents reported experiencing the bullying behaviours less frequently or never. However, in case of those who did experience one or more of the bullying behavioursas outlined by the Olweus Bullying Questionnaire, their frequency of experience was multiple times a week or 2- 3 times a month. The differences in frequency of bullying actions experienced by male and female students are shown in Table 3. Additionally, the table highlights that verbal and social bullying are far more frequent than physical bullying. This breakup is shown in further detail in Table 4.

Table 3: Gender and the Frequency of Bullying Behaviours

\begin{tabular}{|c|c|c|c|c|c|c|c|c|}
\hline \multirow[b]{2}{*}{$\begin{array}{l}\text { Frequency/Bullying } \\
\text { Behaviours }\end{array}$} & \multicolumn{4}{|l|}{ Male } & \multicolumn{4}{|l|}{ Female } \\
\hline & $\begin{array}{l}2 \text { to } 3 \\
\text { times a } \\
\text { month }\end{array}$ & $\begin{array}{l}\text { Multi- } \\
\text { ple } \\
\text { times a } \\
\text { week }\end{array}$ & $\begin{array}{l}\text { Only } \\
\text { once } \\
\text { or } \\
\text { twice }\end{array}$ & Never & $\begin{array}{l}2 \text { to } 3 \\
\text { times a } \\
\text { month }\end{array}$ & $\begin{array}{l}\text { Multi- } \\
\text { ple } \\
\text { times } \\
\text { a } \\
\text { week }\end{array}$ & $\begin{array}{l}\text { Only } \\
\text { once } \\
\text { or } \\
\text { twice }\end{array}$ & Never \\
\hline $\begin{array}{l}\text { Saying mean or } \\
\text { hurtful things }\end{array}$ & 10 & 14 & 28 & 29 & 21 & 14 & 50 & 44 \\
\hline $\begin{array}{l}\text { Ignoring or excluding } \\
\text { the student }\end{array}$ & 5 & 10 & 11 & 55 & 19 & 10 & 43 & 57 \\
\hline $\begin{array}{l}\text { Hitting, kicking, } \\
\text { pushing, shoving or } \\
\text { locking in a room }\end{array}$ & 3 & 2 & 17 & 59 & 5 & 2 & 10 & 112 \\
\hline $\begin{array}{lr}\begin{array}{l}\text { Spreading } \\
\text { rumors, } \\
\text { unpopularity }\end{array} & \begin{array}{r}\text { false } \\
\text { causing }\end{array} \\
\end{array}$ & 3 & 12 & 22 & 44 & 12 & 8 & 44 & 65 \\
\hline $\begin{array}{lr}\text { Sending mean } \\
\text { messages/emails } & \text { or } \\
\text { emailing rumors } & \\
\end{array}$ & 2 & 2 & 14 & 63 & 3 & 5 & 29 & 92 \\
\hline $\begin{array}{l}\text { Posting negatively on } \\
\text { social media }\end{array}$ & 1 & 1 & 11 & 68 & 3 & 1 & 20 & 105 \\
\hline
\end{tabular}


DOI: https://dx.doi.org/10.26808/rs.ca.i10v5.04

Table 4: Bullying Behaviors Ranked by Prevalence (Students)

\begin{tabular}{|l|l|}
\hline Bullying Behaviors & Weighted Prevalence \\
\hline Saying mean or hurtful things & 106.65 \\
\hline Ignoring or excluding the student & 77.16 \\
\hline Spreading false rumors, causing unpopularity & 74.27 \\
\hline Sending mean messages/emails or emailing rumors & 35.23 \\
\hline Hitting, kicking, pushing, shoving or locking in a room & 26.18 \\
\hline Posting negatively on social media & 21.41 \\
\hline
\end{tabular}

Table 4 shows the weighted prevalence of the various bullying behaviours, where weights of $3,2,1$ and 0 respectively were assigned to the responses of frequency of experiencing the behaviors - "Multiple times a week", "2 to 3 times a month", "Only once or twice", and "Never". The weighted prevalence scores indicate that violence and the use of social media for bullying were the least prevalent whereas verbal bullying ("saying mean or hurtful things") and social bullying ("ignoring or excluding the student" and "spreading false rumors causing unpopularity") were most prevalent.

The same question about bullying behaviors as observed by teachers was asked in the survey of teachers. Table 5 shows the weighted prevalence of bullying behaviors indicated by teachers.

Table 5: Bullying Behaviors Ranked by Prevalence (Student)

\begin{tabular}{|l|l|}
\hline Bullying Behaviour & Net Weighted Prevalence \\
\hline Saying mean or hurtful things & 61 \\
\hline Ignoring or excluding the student & 54 \\
\hline Spreading false rumors, causing unpopularity & 37 \\
\hline Sending mean messages/emails or emailing rumors & 28 \\
\hline $\begin{array}{l}\text { Hitting, kicking, pushing, shoving or locking in a } \\
\text { room }\end{array}$ & 19 \\
\hline Posting negatively on social media & 18 \\
\hline
\end{tabular}

The teacher responses revealed that behaviors relating to verbal and social bullying are far more frequent than those relating to physical bullying. The frequency of Bullying Behaviors was weighted in order to gauge the prevalence of the behaviour. Higher frequencies corresponded to a higher weightage multiplier. "Multiple times a week" was weighted 3, "2 to 3 times a month" was weighted 2, "Only once or twice" was weighted 1, and "Never" was weighted 0 . The results depict that teachers generally encounter cases of verbal and social bullying. The low prevalence rate reported for cyberbullying may be credited to the fact that it mainly takes place after school hours and outside school premises. 
DOI: https://dx.doi.org/10.26808/rs.ca.i10v5.04

Table 6: Experience as Bystander to Bullying

\begin{tabular}{|l|l|}
\hline Experience as a Bystander & \% of Respondents \\
\hline Yes & 76.67 \\
\hline No & 23.33 \\
\hline Total & $\mathbf{1 0 0}$ \\
\hline
\end{tabular}

In response to whether students had ever witnessed one or more of the bullying behaviorsbeing perpetrated on other children at school, almost $77 \%$ responded that they had. This confirms that most bullying incidents occur in the presence of bystanders. It also suggests that while students are comfortable about admitting being bystanders to a bullying incident, they may be reluctant to admit to being bullied themselves.

Table 7: Top Three Bystander Responses

\begin{tabular}{|l|l|}
\hline Response & \% of Respondents \\
\hline Ask the bully to stop & 59.52 \\
\hline Call teachers to deal with the situation & 38.57 \\
\hline Call friends to help the victim & 31.43 \\
\hline
\end{tabular}

In response to what their immediate reaction as a Bystander witnessing a bullying incident would be, the most popular response from students was, "Ask the Bully to Stop." This strongly indicates that most Bystanders would directly intervene. This was followed by "Call teachers to deal with the situation" and "Call friends to help the victim" indicating that a significant proportion of student respondents choose to immediately involve teachers and other students. Furthermore, the responses indicate a strong sense of "Bystander Responsibility" as a countermeasure to bullying.

Table 8: Age and Experience asBystander

\begin{tabular}{|c|c|c|c|c|c|c|c|}
\hline \multirow{2}{*}{$\begin{array}{lr}\text { Have you } & \text { witnessed } \\
\text { someone } & \text { else } \\
\text { experiencing } & \text { bullying } \\
\text { behaviors } & \\
\end{array}$} & \multicolumn{7}{|c|}{ Age of the Student } \\
\hline & 12 & 13 & 14 & 15 & 16 & 17 & 18 \\
\hline No & 1 & 4 & 10 & 17 & 9 & 6 & 2 \\
\hline Yes & 3 & 14 & 20 & 30 & 30 & 57 & 7 \\
\hline
\end{tabular}

These findings are quite consistent with those of earlier researchers (Trach et al., 2010). With regard to age differences, previous research indicates that secondary students report significantly lower rates of intervention than elementary students (Stevens, Van Oost, \& de Bourdeaudhuij, 2000). The current study finds that the reporting of bullying as a bystander is highest between the ages of 14 and 17 years. 
DOI: https://dx.doi.org/10.26808/rs.ca.i10v5.04

International Journal of Computer Application (2250-1797)

Issue 10 Volume 5, September- October 2020

Table 9: Top Three Existing Anti-Bullying Measures at Schools (Students)

\begin{tabular}{|l|l|}
\hline Measure & $\begin{array}{l}\text { \% } \\
\text { Respondents }\end{array}$ \\
\hline $\begin{array}{l}\text { Clear rules about what classifies as bullying, and the disciplinary action } \\
\text { taken if it occurs }\end{array}$ & 60.00 \\
\hline A School Counsellor who you can talk to & 32.38 \\
\hline Student Council members that you can talk to & 23.33 \\
\hline
\end{tabular}

Table 7 shows that most schools have clearly defined rules for dealing with bullying. A large proportion of students also mentioned School Counsellors and Student Council members for reporting of bullying. This finding is interesting because both require a clearly defined and communicated system of passing on information about bullying to the school counsellor/student council member. However, 20\% students indicated that there were "No measures at all" for dealing with bullying at their respective schools.

When teachers were asked the same question, their responses were as shown in Table 10.

Table 10: Top Three Existing Anti-Bullying Measures at Schools (Teachers)

\begin{tabular}{|l|l|}
\hline Existing Anti-Bullying Measures & \% of Respondents \\
\hline $\begin{array}{l}\text { Clear rules about what classifies as bullying, and the } \\
\text { disciplinary action taken if it occurs }\end{array}$ & 70.00 \\
\hline A School Counsellor who students can talk to & 46.67 \\
\hline & \\
Playground supervision by teachers during recess & 46.67 \\
\hline
\end{tabular}

Table 10 reveals that teachers believe most schools have clearly defined rules for dealing with bullying, as well as access to a school counsellor, which were also part of the responses of students. Possibly due to it being part of their assigned duties, teachers also mentioned playground supervision as one of the top three anti-bullying measures. Interestingly, 7\% teachers indicated that there were "No measures at all" at their school.

Table 11: Top Four Victim Responses to Bullying

\begin{tabular}{|l|l|}
\hline Response & \% of Respondents \\
\hline Talk to your friends & 53.81 \\
\hline Stand up to the bully & 40.00 \\
\hline Talk to a teacher & 29.05 \\
\hline Talk to your parents & 28.10 \\
\hline
\end{tabular}


DOI: https://dx.doi.org/10.26808/rs.ca.i10v5.04 International Journal of Computer Application (2250-1797) Issue 10 Volume 5, September- October 2020

Table 11 shows the most common responses on being bullied. More than 50 percent choose to confide in their friends, and around 40 percent choose to deal with the incident alone and immediately. Confiding in parents and teachers are also largely popular, although not as much as the previous two. This indicates that students prefer to deal with bullying incidents alone, or by talking to their peers, parents, or teachers. Interestingly, very few students choose to confide in school counsellors or student council members, possibly due to a lack of an easily available communication channel. These findings reiterate the need for a system that helps students to communicate the bullying incident to their teachers, counsellors or student council members.

Table 12: Reasons behind Chosen Responses to Bullying

\begin{tabular}{|l|l|}
\hline Reason & \% of Respondents \\
\hline It feels comfortable & 57.62 \\
\hline It is a faster and easier approach & 39.05 \\
\hline It does not involve anyone other than people close to you & 28.57 \\
\hline
\end{tabular}

Table 12 shows the reasons behind the choice of response to bullying incidents that the students had indicated in the previous question. The findings clearly showcase that students consider "comfort", "swiftness", "ease of approach", and "involving only people close to them" as important criteria while choosing the manner in which they respond to bullying.

Table 13: Existing versus Preferred Bullying Reporting Systems in Schools (Students)

\begin{tabular}{|l|l|l|l|}
\hline \multicolumn{2}{|l|}{ Existing Bullying Reporting Systems } & \multicolumn{2}{|l|}{ Preferred Bullying Reporting Systems } \\
\hline System & $\begin{array}{l}\% \\
\text { Respondents }\end{array}$ & System of \\
Complaint to the teacher & 88.10 & $\begin{array}{l}\text { Complaint to the } \\
\text { teacher }\end{array}$ & 64.29 \\
\hline $\begin{array}{l}\text { An email sent to the } \\
\text { school by parents }\end{array}$ & $\begin{array}{l}\text { A mobile app to report } \\
\text { bullying }\end{array}$ & 30.95 \\
\hline $\begin{array}{l}\text { A written complaint to } \\
\text { the school by parents }\end{array}$ & 20.48 & $\begin{array}{l}\text { Complaint to the } \\
\text { School Counsellor }\end{array}$ & 30.00 \\
\hline
\end{tabular}

Table 13 shows the contrast between existing bullying reporting systems and the reporting systems preferred by the student respondents. 88 percent indicated that currently they reported bullying incidents verbally to their teachers, followed by parental complaints via email or written notes. This showcases that most bullying reporting occurs through conventional channels that are not customized specifically for the purpose of reporting.

On the other hand, in terms of preferred bullying reporting systems, while 64 percent preferred verbal reporting to the teacher, it was a significantly smaller number than the current scenario. Almost 30 percent respondents favoreda mobile app and verbal reporting to school counsellors, showcasing the preference for customized channels for reporting bullying. 
Table 14: Existing Bullying Reporting Systems (Teachers)

\begin{tabular}{|l|l|}
\hline Existing Bullying Reporting Systems & \% of Respondents \\
\hline Verbally to the teacher & 93.33 \\
\hline Verbally to the School Counsellor & 36.67 \\
\hline An email sent to the school by the student's parents & 20.00 \\
\hline & \\
\hline A written complaint to the school by the student's parents & 10.00 \\
\hline $\begin{array}{l}\text { Writing the complaint on a chit and dropping it in a designated } \\
\text { box }\end{array}$ & 6.67 \\
\hline & \\
\hline A form on the school website to report bullying & 3.33 \\
\hline A mobile app to report bullying & 3.33
\end{tabular}

Teachers were asked to indicate how bullying incidents are generally reported in their schools. It was revealed that complaints to the teacher are most widely prevalent, followed by complaints to school counselors and emails sent by the students' parents. The findings support the data provided by students on the subject, with complaints to teachers, complaints by parents via email, and written complaints by parents being most popular of the existing bullying reporting systems. However, there is a stark difference between the claims of teachers and students on the topic complaints to the school counsellor, which indicates that most schools have counsellors but they do not counsel in matters of bullying, contrary to claims by teachers.

Table 15: Relationship between Standard and Choice of Anti-bullying Reporting System

\begin{tabular}{|l|l|l|l|l|l|l|l|}
\hline & $\begin{array}{l}\text { Compl- } \\
\text { aint to } \\
\text { the } \\
\text { teacher }\end{array}$ & $\begin{array}{l}\text { Written } \\
\text { compl- } \\
\text { aint to } \\
\text { the } \\
\text { school } \\
\text { by } \\
\text { parents }\end{array}$ & $\begin{array}{l}\text { Compl- } \\
\text { aint on a } \\
\text { chit } \\
\text { dropped } \\
\text { in a box }\end{array}$ & $\begin{array}{l}\text { Compl- } \\
\text { aint to } \\
\text { the } \\
\text { School } \\
\text { Couns- } \\
\text { ellor }\end{array}$ & $\begin{array}{l}\text { A form on } \\
\text { the school } \\
\text { website to } \\
\text { report } \\
\text { bullying }\end{array}$ & $\begin{array}{l}\text { A } \\
\text { mobile } \\
\text { app to } \\
\text { report } \\
\text { bullying }\end{array}$ & $\begin{array}{l}\text { An email } \\
\text { sent to the } \\
\text { school by } \\
\text { your } \\
\text { parents }\end{array}$ \\
\hline 8 & 11 & 2 & 8 & 7 & 6 & 0 & 5 \\
\hline 9 & 15 & 1 & 3 & 5 & 2 & 1 & 2 \\
\hline 10 & 41 & 7 & 7 & 9 & 3 & 5 & 8 \\
\hline 11 & 18 & 4 & 3 & 5 & 2 & 8 & 4 \\
\hline 12 & 50 & 7 & 6 & 12 & 3 & 18 & 12 \\
\hline
\end{tabular}

The above table denotes that a majority students across every standard would prefer to report the bullying case to the teacher, with increasing preference for mobile in high school 
DOI: https://dx.doi.org/10.26808/rs.ca.i10v5.04 International Journal of Computer Application (2250-1797) Issue 10 Volume 5, September- October 2020

students. However, a mobile app that allows students to choose specific teachers or counsellors to deal with the incident would cater to the reporting needs of all students.

Table 16: Preferred Features in a Bullying Reporting System (Students)

\begin{tabular}{|l|l|l|l|}
\hline Features for Reporting System & $\begin{array}{l}\text { Must be } \\
\text { there }\end{array}$ & $\begin{array}{l}\text { Good to } \\
\text { have }\end{array}$ & $\begin{array}{l}\text { Not very } \\
\text { useful }\end{array}$ \\
\hline $\begin{array}{l}\text { It should be accessible even when you are not in } \\
\text { school }\end{array}$ & 64.29 & 30.95 & 4.76 \\
\hline $\begin{array}{l}\text { You should be able to select from options or write } \\
\text { down your own complaint if you wish to }\end{array}$ & 54.76 & 38.57 & 6.67 \\
\hline A copy of the complaint must be accessible to you & 50.00 & 34.76 & 15.24 \\
\hline $\begin{array}{l}\text { It should allow anonymous communication with } \\
\text { school representatives }\end{array}$ & 48.57 & 42.38 & 9.05 \\
\hline $\begin{array}{l}\text { You should have the option to reveal your identity if } \\
\text { you wish to }\end{array}$ & 41.90 & 46.67 & 11.43 \\
\hline It should be anonymous & 40.48 & 42.86 & 16.67 \\
\hline You should be able to report on behalf of others & 33.33 & 52.86 & 13.81 \\
\hline
\end{tabular}

Respondents were given a list of potential features for a bullying reporting system, and were asked to indicate whether the features were "Not very useful", "Good to have" or "Must be there." A majority of the students indicated that access to the system outside of schools, the ability to quickly register a complaint by checking through a list of options while also having the ability to write in one's own words, and access to complaint copies were necessary features and "Must be there."

Table 17: Most Preferred Mobile App Features (Student)

\begin{tabular}{|l|l|}
\hline Feature & $\begin{array}{l}\text { Net Weighted } \\
\text { Preference }\end{array}$ \\
\hline It should be accessible even when you are not in school & 159.53 \\
\hline $\begin{array}{l}\text { You should be able to select from options or write down your own } \\
\text { complaint if you wish to }\end{array}$ & 148.09 \\
\hline It should allow anonymous communication with school representatives & 139.52 \\
\hline A copy of the complaint must be accessible to you & 134.76 \\
\hline You should have the option to reveal your identity if you wish to & 130.47 \\
\hline It should be anonymous & 123.82 \\
\hline You should be able to report on behalf of others & 119.52 \\
\hline
\end{tabular}


DOI: https://dx.doi.org/10.26808/rs.ca.i10v5.04 International Journal of Computer Application (2250-1797) Issue 10 Volume 5, September- October 2020

The fields were weighted in order to gauge the preference for features. Higher preference corresponded to a higher weightage multiplier. "Must be there" was weighted 2, "Good to have" was weighted 1 , and "Not very useful" was weighted 0 . The most popular features were the ability to access the reporting system outside school, the ability to choose between selecting pre-written fields and self-writing the complaint, and anonymous communication with school representatives. Optional anonymity and access to copies of old complaints were also popular choices. This indicates the students' preference for anytime-use, userfriendliness and anonymity. Contrary to students' responses to be responsible bystanders, the table depicts that reporting on behalf of others is the least preferred feature with almost 14 percent responders claiming that it is not very useful.

Table 18: Relationship between Student Age and Opinion About Mobile App

\begin{tabular}{|l|l|l|l|l|}
\hline Age & $\begin{array}{l}\text { It } \\
\text { anonymous }\end{array}$ & $\begin{array}{l}\text { It can be easily } \\
\text { downloaded on } \\
\text { your phone }\end{array}$ & $\begin{array}{l}\text { It is quick and } \\
\text { easy to use }\end{array}$ & $\begin{array}{l}\text { Options can be } \\
\text { clicked without } \\
\text { writing much }\end{array}$ \\
\hline 12 & 2 & 2 & 2 & 0 \\
\hline 13 & 8 & 9 & 8 & 8 \\
\hline 14 & 11 & 17 & 21 & 13 \\
\hline 15 & 22 & 17 & 31 & 17 \\
\hline 16 & 16 & 12 & 20 & 8 \\
\hline 17 & 36 & 30 & 43 & 35 \\
\hline 18 & 2 & 1 & 4 & 5 \\
\hline
\end{tabular}

Age-wise the most preferred feature of mobile application as a bullying reporting system is reasoned out that it is quick and easy. The older teenagers also preferred the app as it is easy to download and it can be anonymous.

Table 19: Most Preferred Bullying Reporting System Features (Teachers)

\begin{tabular}{|l|l|l|l|l|}
\hline $\begin{array}{l}\text { Features for Reporting } \\
\text { System }\end{array}$ & $\begin{array}{l}\text { Must be } \\
\text { there }\end{array}$ & $\begin{array}{l}\text { Good to } \\
\text { have }\end{array}$ & $\begin{array}{l}\text { Not Very } \\
\text { Useful }\end{array}$ & $\begin{array}{l}\text { Weighted } \\
\text { Scores }\end{array}$ \\
\hline It should be anonymous & 20.00 & 36.67 & 43.33 & 23.00 \\
\hline $\begin{array}{l}\text { It should be accessible even } \\
\text { when the student is not in } \\
\text { school }\end{array}$ & 46.67 & 36.67 & 16.67 & 39.00 \\
\hline $\begin{array}{l}\text { It should allow anonymous } \\
\text { communication with school } \\
\text { representatives }\end{array}$ & 23.33 & 43.33 & 33.33 & 27.00 \\
\hline $\begin{array}{l}\text { A copy of the complaint must } \\
\text { be accessible to the student }\end{array}$ & 46.67 & 23.33 & 30.00 & 35.00 \\
\hline $\begin{array}{l}\text { The student should be able to } \\
\text { report on behalf of others }\end{array}$ & 36.67 & 53.33 & 10.00 & 38.00 \\
\hline $\begin{array}{l}\text { The student should have the } \\
\text { option to reveal his identity if } \\
\text { he wishes to }\end{array}$ & 26.67 & 66.67 & 6.67 & 36.00 \\
\hline $\begin{array}{l}\text { The student should be able to } \\
\text { select from options or write } \\
\text { down his own complaint if he } \\
\text { wishes to }\end{array}$ & 70.00 & 23.33 & 6.67 & 49.00 \\
\hline
\end{tabular}


DOI: https://dx.doi.org/10.26808/rs.ca.i10v5.04 International Journal of Computer Application (2250-1797) Issue 10 Volume 5, September- October 2020

Out of the given list of potential features for a bullying reporting system, teachers' popular features were the ability to choose between selecting pre-written fields and self-writing the complaint, the ability to access the reporting system outside school, and bystander reporting. Optional anonymity and access to copies of old complaints were also popular choices. This showcases parity in the teachers' and students' preference for user-friendliness and anytimeaccess. Additionally, teachers' preference of bystander reporting depicts the commitment to support the reporting of bullying by bystanders.

\section{Conclusion}

The surveys of two major groups of stakeholders revealed some core requirements of an effective bullying reporting system. They are:

- Comfort

- Swiftness

- Ease of approach

- Involving only people close to them

- Customized channels

- Ability to choose specific teachers or counsellors

- Ability to quickly register a complaint by checking through a list of options

- Ability to write the complaint in one's own words

- Access to complaint copies were necessary features

The findings also revealed that students and teachers preferred the following features in a mobile application based bullying reporting system:

- Ability to access the reporting system outside school

- Ability to choose between selecting pre-written fields and self-writing the complaint

- Anonymous communication with school representatives

- Optional anonymity

- Access to copies of old complaints

- Bystander reporting

The researcher used these findings for the design of a bullying reporting mobile application for which this research paper was intended to provide crucial inputs. Using the themes identified above as requirements for an effective bullying reporting system and for a mobile application serving this purpose, the researcher designed the features of the mobile application 'Upstander'.

The figure below shows some of the actual user interfaces of the app 'Upstander'.

Figure 1: User Interfaces of the app 'Upstander'
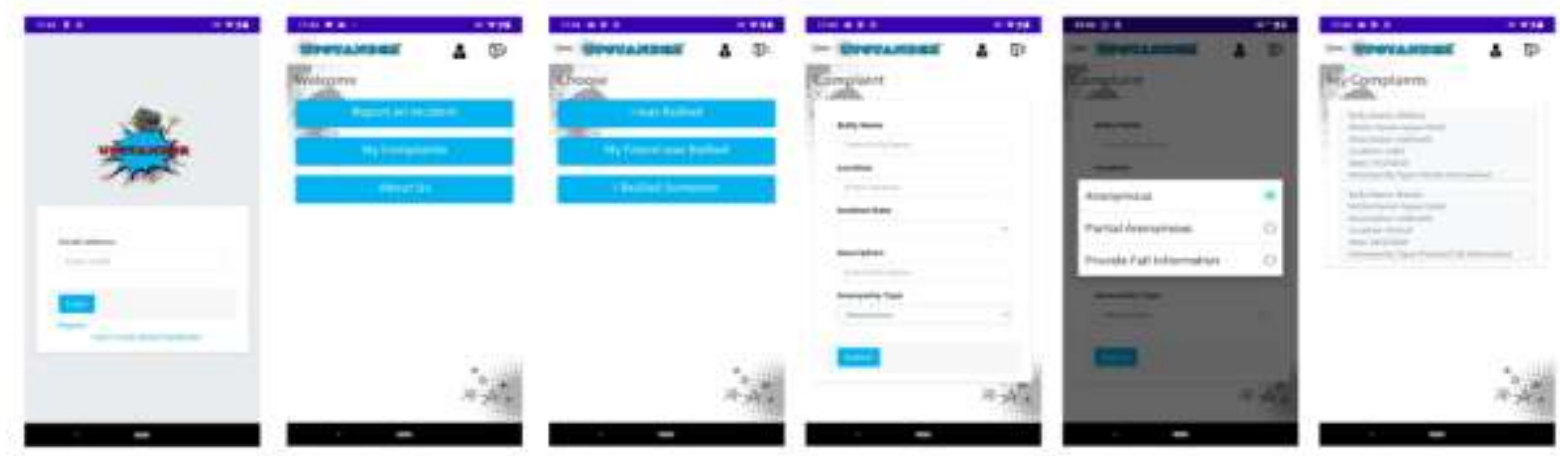
DOI: https://dx.doi.org/10.26808/rs.ca.i10v5.04

International Journal of Computer Application (2250-1797)

Issue 10 Volume 5, September- October 2020

These were designed considering the inputs received from the study about the strong studentpreference for anytime-use, user-friendliness and anonymity, as well as the teacher preference for these features as well as support for bystander reporting.

\section{Discussion}

The participants of the two surveys responded positively to the requirement of an effective bullying reporting system, especially one that is mobile application based.

The most important perceived features were ease and swiftness of use, ability to involve only specific persons in the reporting, ability to choose between selecting pre-written fields and self-writing the complaint, access to complaint, ability to access the reporting system outside school, anonymous communication with school representatives and bystander reporting.

These findings also highlight the importance of allowing adolescents to feel in control of how theyaccess support for their bullying related problems. To achieve this, young people should be involved at allstages of the app development process including, planning, design, delivery and evaluation in line with Coughlan et al (2011).

This research was aimed at assessing the need for, and developing a mobile app for use by adolescents for reporting bullying in Indian schools. The findings of the study have generated important statistics about the bullying experiences of Indian teenagers, on the alternatives available to them for reporting of bullying and their preferences about the features of a bullying reporting mobile app. Using a multi-stakeholder approach, this has research also brought forth important findings about the perspective of Indian schoolteachers on bullying reporting systems for their students.

The insights generated by this research have been incorporated into the development of the mobile application 'Upstander' available on Google Play Store and Web. A key challenge faced by future developers of other bullying related mobile technologies in India will be balancing the preferences of adolescents for advanced features in such apps on one hand, and feasibility, design and development constraints on the other. The findings of this study will provide a valuable reference point for such developers and will help ensure that such technologies are developed in a manner that they become acceptable and engaging for adolescents, in order to maximise their overall reach and impact.

In terms of limitations of the study, this research focussed on students and teachers from schools of Ahmedabad city only. Further research can be conducted to understand the preferences of students and teachers from all over India and find out similarities and differences in perspectives.

\section{References}

1. "88 per Cent of Adolescents Own Mobile Phone in India." The Mobile Indian, 6 Dec. 2010, www.themobileindian.com/news/88-per-cent-of-adolescents-own-mobile-phone-inindia-528. Accessed 16 Oct. 2020.

2. Aboud, F., \& Miller, L. (2007). Promoting peer intervention in name-calling. South African Journal of Psychology, 37, 803-819.

3. Ahmed, E., \& Braithwaite, V. (2004). Bullying and victimization: Cause for concern for both families and schools. [Article]. Social Psychology of Education, 7(1), 35-54.

4. Allen, K. P. 2010a. A bullying intervention system in high school: A two-year schoolwide follow-up. Studies in Educational Evaluation, 36(3): 83-92. 
DOI: https://dx.doi.org/10.26808/rs.ca.i10v5.04 International Journal of Computer Application (2250-1797) Issue 10 Volume 5, September- October 2020

5. Allen, K. P. 2010b. A bullying intervention system: Reducing risk and creating support for aggressive students. Preventing School Failure, 54(3): 199-209.

6. Althoff, T., Clark, K., \& Leskovec, J. (2016). Large-scale analysis of counseling conversations: An application of natural language processing to mental health. Transactions of the Association for Computational Linguistics, 4(1), 463-476.

7. Arroyo, I., Woolf, B. P., Cooper, D. G., Burleson, W., \& Muldner, K. (2011, July). The impact of animated pedagogical agents on girls' and boys' emotions, attitudes, behaviors and learning. Proceedings of the 2011 IEEE 11th International Conference on Advanced Learning Technologies (pp. 506-510). Athens, GA: IEEE.

8. Bhat, Christine Suniti, et al. "Online Bullying among High-School Students in India." International Journal for the Advancement of Counselling, vol. 39, no. 2, 20 Feb. 2017, pp. 112-124, 10.1007/s10447-017-9286-y. Accessed 4 Oct. 2020.

9. Bonanno, R., \& Hymel, S. (2006a, May). Witnessing bullying: Assessing exposure and negative consequences. Poster presented at the Promoting Relationships and Eliminating Violence (PREVNet) National Centre of Excellence-New Initiative (NCE-NI) first international conference, Carleton University, Ottawa, ON.

10. Bonanno, R., \& Hymel, S. (2006b, July 2-6). Exposure to school violence: The impact of bullying on witnesses. Paper presented at the 19th biennial meeting of the International Society for the Study of Behavior Development, Melbourne, Australia.

11. Bradshaw, C. P., Sawyer, A. L., \& O’Brennan, L. M. (2007). Bullying and peer victimization at school: Perceptual differences between students and school staff. School Psychology Review, 36, 361-382.

12. Breton, Emily R., Bernard F. Fuemmeler, and Lorien C. Abroms. "Weight loss - there is an app for that! But does it adhere to evidence-informed practices?." Translational behavioral medicine 1.4 (2011): 523-529.

13. Coughlan H, Cannon M, Shiers $D$, et al. Towards a new paradigm of care: the international declaration on Youth Mental Health. Early Interv Psychiatry 2011; 7(2): $103-108$.

14. Craig, W., \& Pepler, D. (1997). Observations of bullying and victimization in the schoolyard. Canadian Journal of School Psychology, 2, 41-60.

15. Evans, Caroline B.R., et al. "The Effectiveness of School-Based Bullying Prevention Programs: A Systematic Review." Aggression and Violent Behavior, vol. 19, no. 5, Sept. 2014, pp. 532-544, 10.1016/j.avb.2014.07.004. Accessed 4 Oct. 2020.

16. Farrington, David P., and Maria M. Ttofi. "School-Based Programs to Reduce Bullying and Victimization." Campbell Systematic Reviews, vol. 5, no. 1, Jan. 2009, 10.4073/csr.2009.6. Accessed 4 Oct. 2020.

17. Fitch, T., Newby, E., Ballestero, V., \& Marshall, J. (2001). Future school administrators' perceptions of the school counselor's role. Counselor Education \& Supervision, 41(2), 89.

18. Frey, K. S., Hirschstein, M. K., Edstrom, L. V., \& Snell, J. L. (2009). Observed reductions in school bullying, nonbullying aggression and destructive bystander behavior: Alongitudinal evaluation. Journal of Educational Psychology, 101(2), 466-481.

19. Graesser, A. C., \& McDaniel, B. (2007). Conversation agents can provide formative assessment, constructive learning, and adaptive instruction. In Dwyer, C. A. (Ed.), The future of assessment: Shaping teaching and learning (pp. 85-112). Mahwah, NJ: Erlbaum.

20. Graham, Sandra. "What educators need to know about bullying behaviors." Phi Delta Kappan 92.1 (2010): 66-69.

21. Heron, Kristin E., and Joshua M. Smyth. "Ecological momentary interventions: incorporating mobile technology into psychosocial and health behaviour treatments." British journal of health psychology 15.1 (2010): 1-39. 
DOI: https://dx.doi.org/10.26808/rs.ca.i10v5.04 International Journal of Computer Application (2250-1797) Issue 10 Volume 5, September- October 2020

22. Holt, M. K., Kaufman Kantor, G., \& Finkelhor, D. (2009). Parent/child concordance about bullying involvement and family characteristics related to bullying and peer victimization. [Article]. Journal of School Violence, 8(1), 42-63. doi: 10.1080/15388220802067813

23. Kanetsuna, T., Smith, P. K., \& Morita, Y. (2006). Coping with bullying at school: Children's recommended strategies and attitudes to school-based interventions in England and Japan. Aggressive Behavior, 32, 570-580.

24. Kenny, Rachel, Barbara Dooley, and Amanda Fitzgerald. "Developing mental health mobile apps: exploring adolescents' perspectives." Health informatics journal 22.2 (2016): 265-275.

25. Kodad, H. S., and S. A. Kazi. "Emerging area of counselling in schools in India." International Research Journal of Social Sciences 3.3 (2014): 44-47.

26. Kshirsagar, V. Y., Rajiv Agarwal, and Sandeep B. Bavdekar. "Bullying in schools: prevalence and short-term impact." Indian pediatrics 44.1 (2007): 25.

27. Lanigan, Ashley R. "A Systematic Review of Bullying Prevention Programs in Schools." (2015).

28. Law, Danielle M., et al. "The changing face of bullying: An empirical comparison between traditional and internet bullying and victimization." Computers in Human Behavior 28.1 (2012): 226-232.

29. Lee, Seungha, Peter K. Smith, and Claire P. Monks. "Meaning and usage of a term for bullying-like phenomena in South Korea: A lifespan perspective." Journal of Language and Social Psychology 31.3 (2012): 342-349.

30. Limper, R. (2000). Cooperation between parents, teachers, and school boards to prevent bullying in education: An overview of work done in the Netherlands. Aggressive Behavior, 26(1), 125-134.

31. Malhi, Prahbhjot, et al. "Aggression in Schools: Psychosocial Outcomes of Bullying Among Indian Adolescents." The Indian Journal of Pediatrics, vol. 81, no. 11, 23 Mar. 2014, pp. 1171-1176, 10.1007/s12098-014-1378-7. Accessed 4 Oct. 2020.

32. Matthews, Mark, et al. "Designing mobile applications to support mental health interventions." Handbook of research on user interface design and evaluation for mobile technology. IGI Global, 2008. 635-656.

33. Maunder, Rachel E., Alex Harrop, and Andrew J. Tattersall. "Pupil and staff perceptions of bullying in secondary schools: comparing behavioural definitions and their perceived seriousness." Educational research 52.3 (2010): 263-282.

34. Maunder, Rachel E., and Sarah Crafter. "School bullying from a sociocultural perspective." Aggression and violent behavior 38 (2018): 13-20.

35. Maunder, Rachel E., and Sarah Crafter. "School Bullying from a Sociocultural Perspective." Aggression and Violent Behavior, vol. 38, Jan. 2018, pp. 13-20, 10.1016/j.avb.2017.10.010. Accessed 4 Oct. 2020.

36. McCarthy, N. (2019). "The Cost Of Mobile Internet Around The World". Forbes.com. Available at https://www.forbes.com/sites/niallmccarthy/2019/03/05/the-cost-of-mobileinternet-around-the-world-infographic/\#6edbe608226e

37. Menesini, Ersilia, Ada Fonzi, and Peter K. Smith. "Attribution of meanings to terms related to bullying: A comparison between teacher's and pupil's perspectives in Italy." European Journal of Psychology of Education 17.4 (2002): 393.

38. Milsom, Amy, and Laura L. Gallo. "Bullying in Middle Schools: Prevention and Intervention." Middle School Journal, vol. 37, no. 3, Jan. 2006, pp. 12-19, 10.1080/00940771.2006.11461531. Accessed 4 Oct. 2020. 
DOI: https://dx.doi.org/10.26808/rs.ca.i10v5.04 International Journal of Computer Application (2250-1797) Issue 10 Volume 5, September- October 2020

39. Mishna, F., Pepler, D., \& Wiener, J. (2006). Factors associated with perceptions and responses to bullying situations by children, parents, teachers, and principals. Victims and Offenders, 1, 255-288.

40. Morgan, Hani. "What teachers and schools can do to control the growing problem of school bullying." The Clearing House: A Journal of Educational Strategies, Issues and Ideas 85.5 (2012): 174-178.

41. Morgan, Hani. "What Teachers and Schools Can Do to Control the Growing Problem of School Bullying." The Clearing House: A Journal of Educational Strategies, Issues and Ideas, vol. 85, no. 5, 11 July 2012, pp. 174-178, 10.1080/00098655.2012.677075. Accessed 4 Oct. 2020.

42. Naylor, Paul, et al. "Teachers' and pupils' definitions of bullying." British journal of educational psychology 76.3 (2006): 553-576.

43. Nocentini, A., Zambuto, V., \& Menesini, E. (2015). Anti-bullying programs and Information and Communication Technologies (ICTs): A systematic review. Aggression and Violent Behavior, 23(1), 52-60.

44. Noorhidawati, Abdullah, S. Ghazal Ghalebandi, and R. Siti Hajar. "How do young children engage with mobile apps? Cognitive, psychomotor, and affective perspective." Computers \& Education 87 (2015): 385-395.

45. Novick, R. M., and J. Isaacs. 2010. Telling is compelling: The impact of student reports of bullying on teacher intervention. Educational Psychology 30(3): 2

46. Novick, Rona Milch, and Jenny Isaacs. "Telling is compelling: The impact of student reports of bullying on teacher intervention." Educational Psychology 30.3 (2010): 283296.

47. O’Connell, P., Pepler, D., \& Craig, W. (1999). Peer involvement in bullying: Insights and challenges for intervention. Journal of Adolescence, 22, 437-452.

48. Olweus, D. "Victimization by peers: Antecedents and long-term outcomes. Teoksessa Rubin, K. \& Asendorpf, J.(toim.) Social withdrawal, inhibition and shyness in childhood." (1993): 315-341.

49. Olweus, D. (1993). Victimisation by peers: Antecedents and long-term outcomes. In K. H. Rubin \& J. B. Asendorpf (Eds.), Social withdrawal, inhibition and shyness in childhood (pp. 315-341). Hillsdale, NJ: Lawrence Erlbaum.

50. Olweus, Dan. "School bullying: Development and some important challenges." Annual review of clinical psychology 9 (2013): 751-780.

51. Olweus, Dan. "School bullying: Development and some important challenges." Annual review of clinical psychology 9 (2013): 751-780.

52. Olweus, Dan. "Revised Olweus Bully/Victim Questionnaire." PsycTESTS Dataset, 2006, 10.1037/t09634-000. Accessed 4 Oct. 2020.

53. Olweus, Dan. Aggression in the schools: Bullies and whipping boys. Hemisphere, 1978.

54. Peterson-Sweeney, Kathleen. "The use of focus groups in pediatric and adolescent research." Journal of Pediatric Health Care 19.2 (2005): 104-110.

55. Proudfoot, Judith. "The future is in our hands: the role of mobile phones in the prevention and management of mental disorders." Australian \& New Zealand Journal of Psychiatry 47.2 (2013): 111-113.

56. Ramya, S. G., and Mulrlidhar L. Kulkarni. "Bullying Among School Children: Prevalence and Association with Common Symptoms in Childhood." The Indian Journal of Pediatrics, vol. 78, no. 3, 20 Oct. 2010, pp. 307-310, 10.1007/s12098-010-0219-6. Accessed 4 Oct. 2020.

57. Rigby, K. (2011). What can schools do about cases of bullying? Pastoral Care in Education, 29(4), 273-285. 
DOI: https://dx.doi.org/10.26808/rs.ca.i10v5.04

International Journal of Computer Application (2250-1797)

Issue 10 Volume 5, September- October 2020

58. Rigby, Ken, and Peter K. Smith. "Is school bullying really on the rise?." Social Psychology of Education 14.4 (2011): 441-455.

59. Rocke Henderson, N. (2002). Peer response to bullying conflict: Identifying early adolescents' strategies and goal. Unpublished master's thesis, University of British Columbia, Vancouver, Canada.

60. Salmivalli, C. (1999). Participant role approach to school bullying: Implications for interventions. Journal of Adolescence, 22, 453-459.

61. Salmivalli, C., \& Peets, K. (2009). Bullies, victims, and bully-victim relationships in middle childhood and early adolescence. In K. H. Rubin, W. M. Bukowski, \& B. Laursen (Eds.), Handbook of peer interactions, relationships and groups (pp. 322-340). New York: Guilford.

62. Salmivalli, C., Lagerspetz, K., Bjorkqvist, K., Osterman, K., \& Kaukiainen, A. (1996). Bullying as a group process: Participant roles and their relations to social status within the group. Aggressive Behavior, 22, 1-15.

63. Salmivalli, C., Lappalainen, M., \& Lagerspetz, K. (1998). Stability and change of behavior in connection with bullying in schools: A two-year follow-up. Aggressive Behavior, 24, 205-218.

64. Smith, Peter K., and Claire P. Monks. "Concepts of bullying: Developmental and cultural aspects." APublic HEALTH CONCERN (2008): 3.

65. Smith, Peter K., and Sara Levan. "Perceptions and experiences of bullying in younger pupils." British Journal of Educational Psychology 65.4 (1995): 489-500.

66. Smith, Peter K., et al. "Definitions of bullying: A comparison of terms used, and age and gender differences, in a Fourteen-Country international comparison." Child development 73.4 (2002): 1119-1133.

67. Smith, Peter K., Katerina Ananiadou, and Helen Cowie. "Interventions to reduce school bullying." The Canadian Journal of Psychiatry 48.9 (2003): 591-599.

68. Solomon, R. J., et al. "A cross-national comparison of adolescent bullying victimization in Mumbai India, Melbourne Australia and Seattle US." XXVII International Population Conference, Busan, Korea. 2013.

69. Song,D., Oh, E., \& Rice, M. (2017, July). Interacting with a conversational agent system for educational purposes in online courses. Proceedings of the 10th International Conference on Human System Interaction (HSI) (pp. 78-82). Ulsan, South Korea: IEEE.

70. Sophia, Sophia, and Ashley Lanigan. A Systematic Review of Bullying Prevention Programs in Schools A Systematic Review of Bullying Prevention Programs in Schools. 2015.

71. Srisiva, R., R. Thirumoorthi, and P. Sujatha. "Prevalence and prevention of school bullying-a case study of Coimbatore City, Tamilnadu, India." International Journal of Humanities and Social Science Invention 2.1 (2013): 2319-7714.

72. Standard, I. S. O., and B. ISO. "ISO 9241-210: 2010-Ergonomics of human-system interaction-Part 210: Human-centred design for interactive systems." Geneva, Switzerland (2010): 27.

73. Stevens, V., Van Oost, P., \& De Bourdeaudhuij, I. (2000). The effects of an anti-bullying inter-vention programme on peers' attitudes and behaviour. Journal of Adolescence, 23, 21-34.

74. Sundaram, S., and E. J. Alexander. "Bullying behaviours among middle school students in Tamil Nadu (South India)." Bullying and Cyberbullying: The Interface between Science and Practice, Vienna, Austria (2012).

75. Trach, Jessica, et al. "Bystander responses to school bullying: A cross-sectional investigation of grade and sex differences." Canadian journal of school psychology 25.1 (2010): 114-130. 
DOI: https://dx.doi.org/10.26808/rs.ca.i10v5.04 International Journal of Computer Application (2250-1797) Issue 10 Volume 5, September- October 2020

76. Venkatesan, S., and H. R. Shyam. "Professional identity of school counselors in India." Journal of the Indian Academy of Applied Psychology 41.1 (2015): 25.

77. Williams, Kirk R., and Nancy G. Guerra. "Prevalence and predictors of internet bullying." Journal of adolescent health 41.6 (2007): S14-S21.

78. Yeager, David Scott, et al. "Declines in Efficacy of Anti-Bullying Programs among Older Adolescents: Theory and a Three-Level Meta-Analysis." Journal of Applied Developmental Psychology, vol. 37, Mar. 2015, pp. 36-51, 10.1016/j.appdev.2014.11.005. Accessed 4 Oct. 2020.

79. Young Oh, Eun, Donggil Song, and Hyeonmi Hong. "Interactive computing technology in anti-bullying education: The effects of conversation-bot's role on K-12 students' attitude change toward bullying problems." Journal of Educational Computing Research 58.1 (2020): 200-219. 